\title{
Firing Resistance of Ordinary Portland Cement Pastes Incorporated a Waste of Building Bricks
}

\author{
Hassan Hassanien Mohamed Darweesh \\ Department of Refractories, Ceramics and Building Materials, National Research Centre, Dokki, Cairo, Egypt
}

Email address:

hassandarweesh777@gmail.com

\section{To cite this article:}

Hassan Hassanien Mohamed Darweesh. Firing Resistance of Ordinary Portland Cement Pastes Incorporated a Waste of Building Bricks. American Journal of Chemical Engineering. Vol. 5, No. 6, 2017, pp. 140-146. doi: 10.11648/j.ajche.20170506.14

Received: July 24, 2017; Accepted: August 21, 2017; Published: November 17, 2017

\begin{abstract}
Addition of fine materials, as clay bricks or Homra (H) to Ordinary Portland cement (OPC) is evidently increases resistance to firing. Effect of firing temperature on physical, mechanical properties and phase composition of cement pastes is investigated. $\mathrm{H}$ can react with lime liberated from hydration of OPC. This improves morphology and microstructure of formed hydration products. OPC cement was partially substituted by $0,5,15,25$ and $35 \mathrm{wt} . \% \mathrm{H}$. Cement pastes were subjected to firing for 3 hours at temperatures $100,200,300400,500$ and $600^{\circ} \mathrm{C}$. Results showed that loss on ignition of various cement pastes increased with temperature as well as with $\mathrm{H}$. Density decreased with temperature up to $400^{\circ} \mathrm{C}$, while porosity increased, Above $400^{\circ} \mathrm{C}$, density increased and porosity decreased. Compressive strength of OPC pastes increased with temperature up to $500^{\circ} \mathrm{C}$ and then decreased. Those incorporated $\mathrm{H}$ increased only up to $400^{\circ} \mathrm{C}$ and then decreased. Hardened cement pastes with $15 \% \mathrm{H}$ recorded highest compressive strength value at $400^{\circ} \mathrm{C}$ while the $\mathrm{OPC}$ at $500^{\circ} \mathrm{C}$. SEM images showed a microstructure of well-developed crystals of $\mathrm{CSH}$ and $\mathrm{CAH} . \mathrm{Ca}(\mathrm{OH})_{2}$ are spreading in matrix at temperatures up to $400^{\circ} \mathrm{C}$. There are some cracks at $600^{\circ} \mathrm{C}$.
\end{abstract}

Keywords: Homra, Pozzolanic, Temperature, Density, Porosity, Strength, Microstructure, SEM

\section{Introduction}

\subsection{Scope of the Study}

When the building materials are exposed to fire, some deterioration effects can occur. This can often reach to a level at which the structure may have to be thoroughly renovated or completely replaced. Heat resistance materials are usually used for structural purposes. The need for such building materials is particularly important in the chemical and metallurgical industries, and also for the thermal shielding of nuclear power plants. The hydrated Portland cement pastes contain a large amount of $\mathrm{Ca}(\mathrm{OH})_{2}$, which dehydrated to $\mathrm{CaO}$ between $500^{\circ} \mathrm{C}$ and $600^{\circ} \mathrm{C}$. Exposure to moisture, the $\mathrm{CaO}$ is rehydrated to $\mathrm{Ca}(\mathrm{OH})_{2}$ with a volume expansion of $97 \%$ accompanied with the formation of cracks $[1,2]$. The pozzolanic materials can react with liberated lime from ordinary Portland cement (OPC) forming additional amounts of calcium silicate hydrates. The replacement of OPC by 10 wt. $\%$ silica fume improves the physicomechanical properties as well as the microstructure of concrete when exposed to elevated temperatures $[3,4]$.

The Portland cement containing $20 \pm 30$ wt.\% fly ash thus possesses a good fire resistance and dimensional stability when exposed to high temperature and then high humidity or wetting $[5,6]$. The replacement of OPC by $20 \mathrm{wt} . \%$ of thermally activated kaolinite in cement paste increases its thermal stability against temperature up to $600^{\circ} \mathrm{C}$ [7].

Homra (crushed clay bricks) is a solid waste material, which is constituted mainly of silica quartz, aluminosilicate, anhydrite, and hematite. Therefore, it acts as a pozzolanic material $[6,8]$. The effect of Homra on the main hydration characteristics of Portland cement at early ages by means of electrical conductivity measurements as well as the physicochemical and mechanical characteristics up to 90 days was studied [9-11].

\subsection{Objectives of the Study}

The objective of his work is to investigate the effect of elevated temperatures on the physical and mechanical properties as well as the microstructure of thermally treated cement pastes containing Homra. 


\section{Experimental Work}

\subsection{Raw Materials}

The used raw materials in this research study was Ordinary Portland cement (OPC) and Homra $(\mathrm{H})$ which is a broken waste of fired bricks $(\mathrm{H})$ having a blaine surface area 3500 and $4100 \mathrm{~cm}^{2} / \mathrm{g}$, respectively. The XRD patterns of $\mathrm{H}$ are shown in Figure 1. It is mainly composed of Quartz, Albite and Hematite. The OPC cement was partially substituted by $\mathrm{H}$ with ratios of $0,5,15,25$ and 35 wt.\% which were given the symbols $\mathrm{H} 0, \mathrm{H} 1, \mathrm{H} 2, \mathrm{H} 3$ and $\mathrm{H} 4$. The chemical compositions of raw materials are recorded in Table 1. The water of consistency and setting times (initial and final) of each cement batch $[12,13]$ were determined using Vicat Apparatus (Figure 2).

Table 1. Chemical composition of raw materials, mass $\%$

\begin{tabular}{|c|c|c|c|c|c|c|c|c|c|c|c|}
\hline Oxide Material & LOI & $\mathrm{SiO}_{2}$ & $\mathbf{A l}_{2} \mathbf{O}_{3}$ & $\mathrm{Fe}_{2} \mathrm{O}_{3}$ & $\mathrm{CaO}$ & MgO & $\mathrm{Na}_{2} \mathrm{O}$ & $\mathbf{K}_{2} \mathbf{O}$ & $\mathrm{SO}_{3}$ & $\mathrm{TiO}_{2}$ & Fineness, $\mathrm{cm}^{2} / \mathrm{g}$ \\
\hline $\mathrm{OPC}$ & 2.64 & 20.12 & 5.25 & 3.38 & 63.13 & 1.53 & 0.55 & 0.31 & 0.3 & 1.86 & 3500 \\
\hline $\mathrm{H}$ & ---- & 58.22 & 28.25 & 8.16 & 0.79 & 0.46 & 1.32 & 1.64 & ---- & 1.34 & 4100 \\
\hline
\end{tabular}

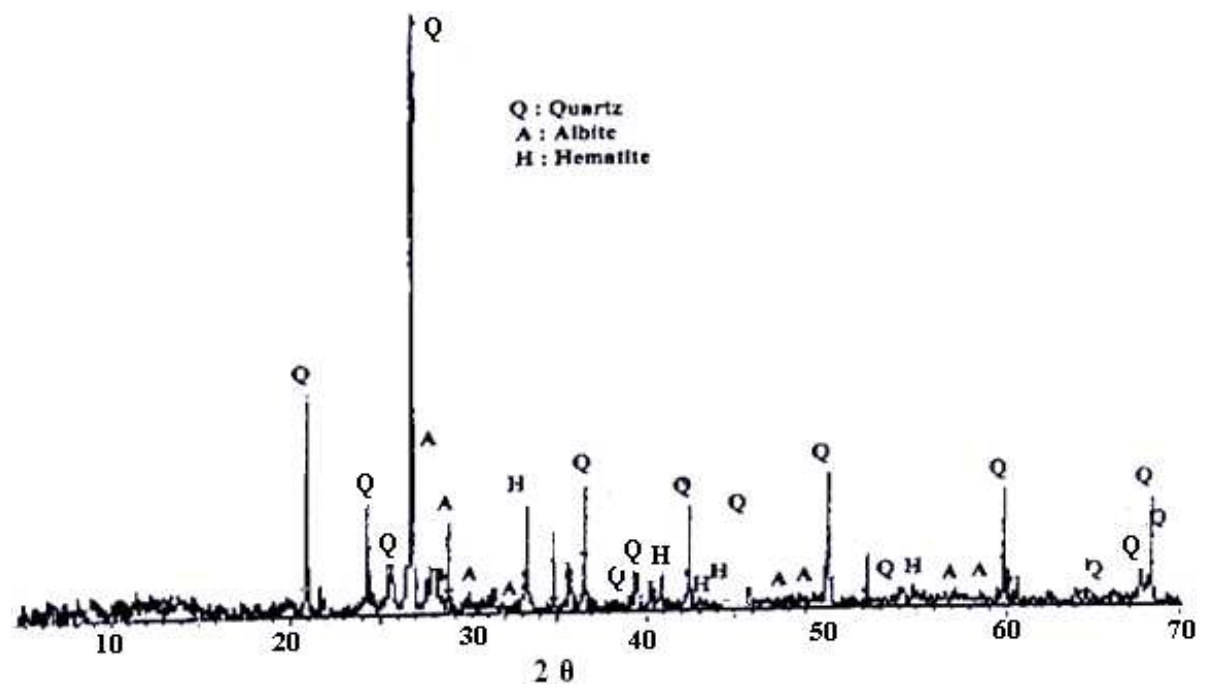

Figure 1. The XRD patterns of Homra waste (H). (Q: Quartz, A: Albite, H: Hematite.

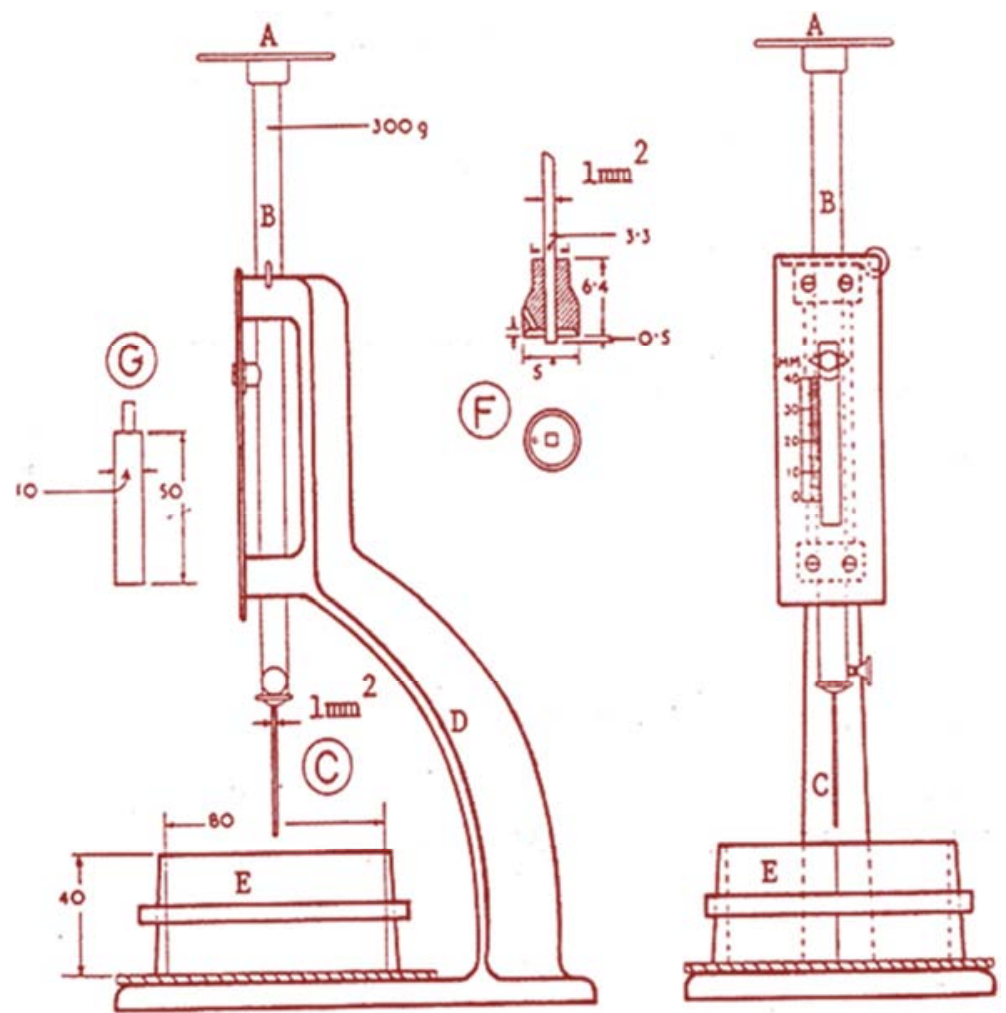

Figure 2. Vicat apparatus for determining the standard consistency water of and setting times of Portland cement pastes. 


\subsection{Preparation and Methods}

The cement pastes of each batch were prepared using the measured amount of water of consistency. The cement pastes were mixed and molded into one inch cubic stainless steel molds. The molds were vibrated manually for 2 minutes to get rid of any air bubbles or voids. Then, it vibrated mechanically for another 2 minutes to ensure the complete elimination of all air bubbles. The surfaces of the pastes were smoothed using a suitable spatula. At once after molding, the specimens were kept in a humidity chamber at room temperature and $100 \%$ Relative humidity for 24 hours. In the following day, it was demolded and soon cured under water up to 28 days taking into consideration that water was daily changed. The density, apparent porosity and compressive strength were then measured, which were considered as zero readings. The hardened cement pastes were then dried at $105^{\circ} \mathrm{C}$ for 24 hours. The hardened cement pastes of all batches were subjected to temperature for 3 hours at 100 , $200,300,400,500$ and $600^{\circ} \mathrm{C}$. They let to cool over night till room temperature. After cooling, the ignition loss, apparent porosity, bulk density and compressive strength were determined [14-16].

Scanning electron microscopy (SEM) of the fractured surfaces, coated with a thin layer of gold by JEOL-JXA-840 electron probe microanalyzer at accelerating voltage of 30 $\mathrm{KV}$ was used to identify the changes that are occurring in the microstructure of the formed or decomposed phases during hydration and heating to study the crystal morphology.

\section{Results and Discussion}

\subsection{Water of Consistency and Setting Times}

The water of consistency and setting times of the different OPC/Homra cement mixes (H0, H1, H2, H3 and H4) are shown in Figure 3. The water of consistency increased as the content $\mathrm{H}$ increased and also did the setting times (Initial and final). This is essentially attributed to the nature of $\mathrm{H}$ which is voracious for water and it is necessary to proceed pozzolanic reactions between $\mathrm{H}$ and the evolved $\mathrm{Ca}(\mathrm{OH})_{2}$ from the hydration process $[6,7]$.

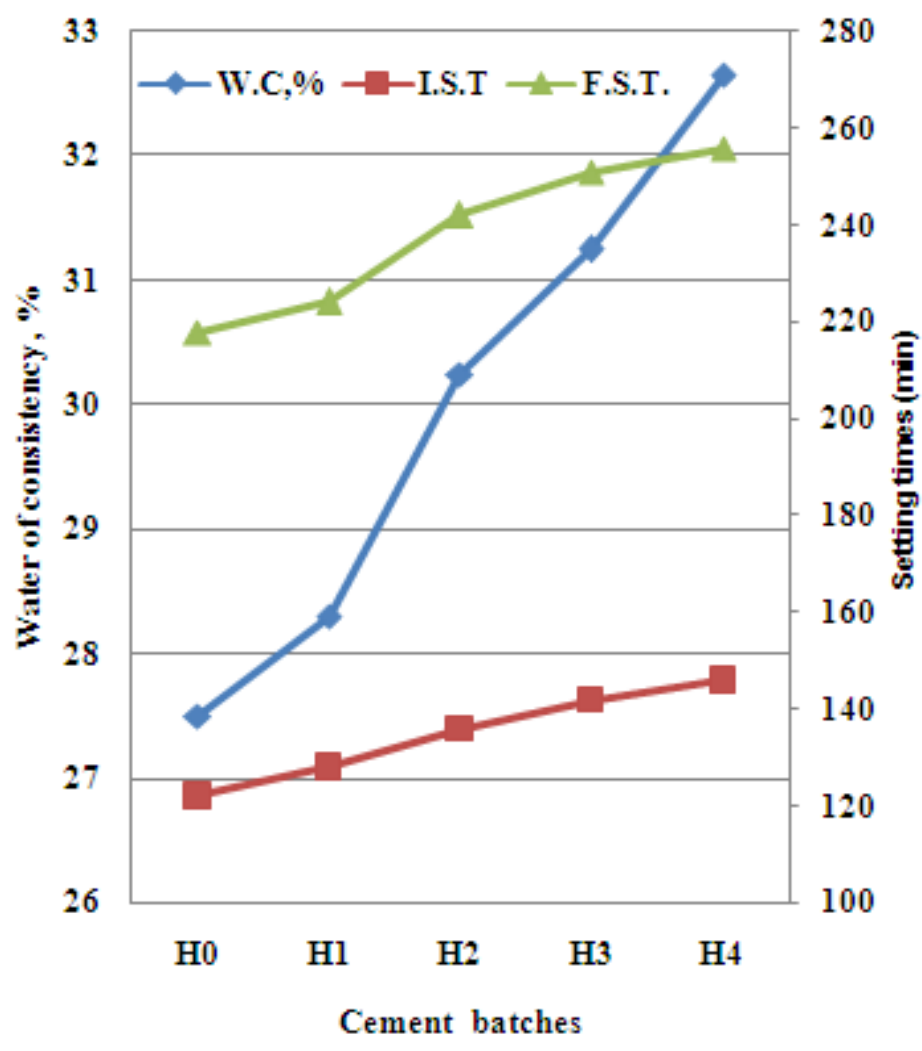

Figure 3. Water of consistency and setting times of the OPC/ Homra cement mixes.

\subsection{Loss on Ignition Loss}

Figure 4 illustrates the relation between the loss on ignition of the hardened cement pastes and temperature was investigated. It is clear that the loss on ignition increased as the temperature increased. This is mainly attributed to the occurrence of some chemical reactions in the usual phases of cement pastes that stimulated on firing as:- 1-Thefree water content found in the intermolecular spaces was removed nearly at $110^{\circ} \mathrm{C}$. 2- A slight decomposition of calcium silicate and/or aluminate hydrates (CSH and CAH) occurred at about $200-250^{\circ} \mathrm{C}$. 3- The braking down of gehlenite hydrate phase $\left(\mathrm{C}_{2} \mathrm{ASH}_{8}\right)$ at about $300^{\circ} \mathrm{C}$ or little more. 4-The dehydration of calcium hydroxide, $\mathrm{Ca}(\mathrm{OH})_{2}$ at $400-600^{\circ} \mathrm{C}$ also occurred. Addition of $\mathrm{H}$ increased the loss on ignition which is essentially contributed to the relatively high water consistency of the cement pastes containing $\mathrm{H}$. As it is obvious, the loss on ignitions took place in three steps. 


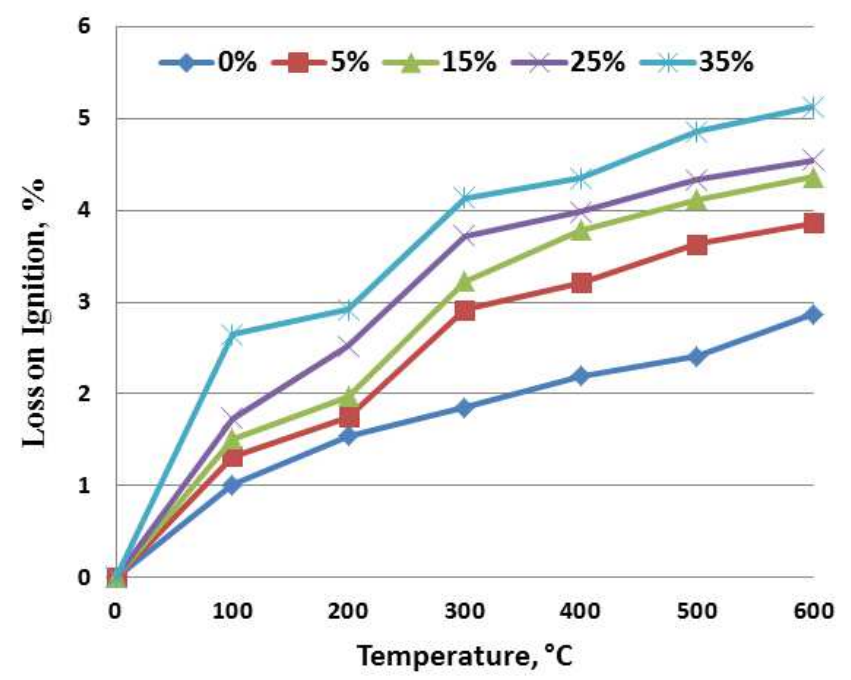

Figure 4. Loss on ignition of cement pastes as a function of temperature up to $600^{\circ} \mathrm{C}$.

\subsection{Bulk Density and Apparent Porosity}

Figures 5 and 6 show the density and porosity of the hardened cement pastes as a function of temperature, respectively. The density decreased as the $\mathrm{H}$ content increased and also as the degree of temperature enhanced up to $400^{\circ} \mathrm{C}$, and then increased if the temperature raised more than $400^{\circ} \mathrm{C}$. On contrast, the porosity increased up to $400^{\circ} \mathrm{C}$ and then decreased. The decrease of bulk density and the increase of apparent porosity are mainly due to the primarily high w/c-ratios used to prepare the original and suitable cement pastes and also, to the relatively low density of $\mathrm{H}$ if compared to that of the OPC that may lead to an open pore structure in the cement pastes [3,14]. On the other side, the increase of density and the decrease porosity is often due to the development and improving of the crystal nature and also may be due to the pozzolanic character of $\mathrm{H}$ in the cement pastes in the beginning of the hydration process which later initiated by thermal treatments [15-17].

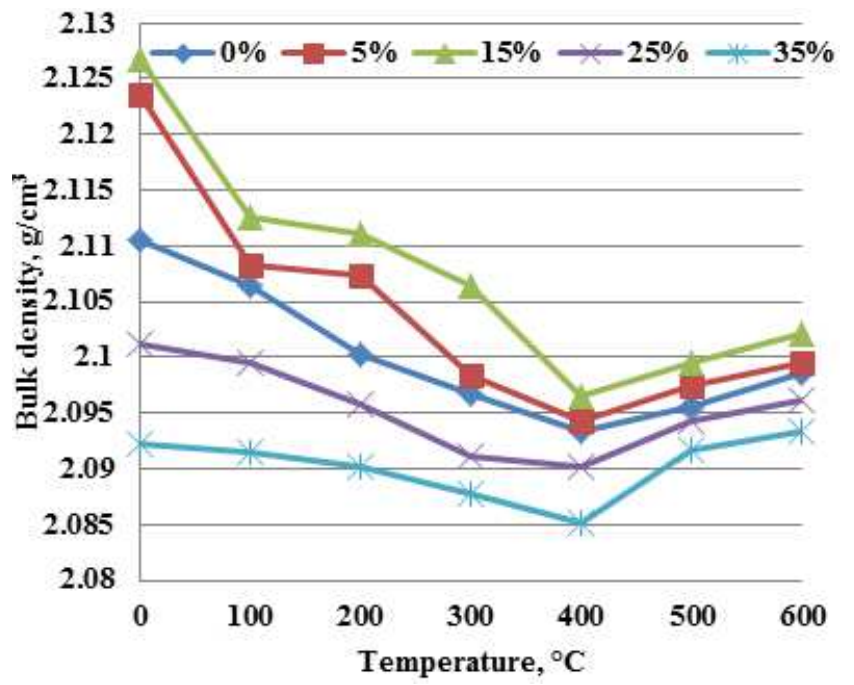

Figure 5. Bulk density of cement pastes as a function of temperature up to $600^{\circ} \mathrm{C}$.

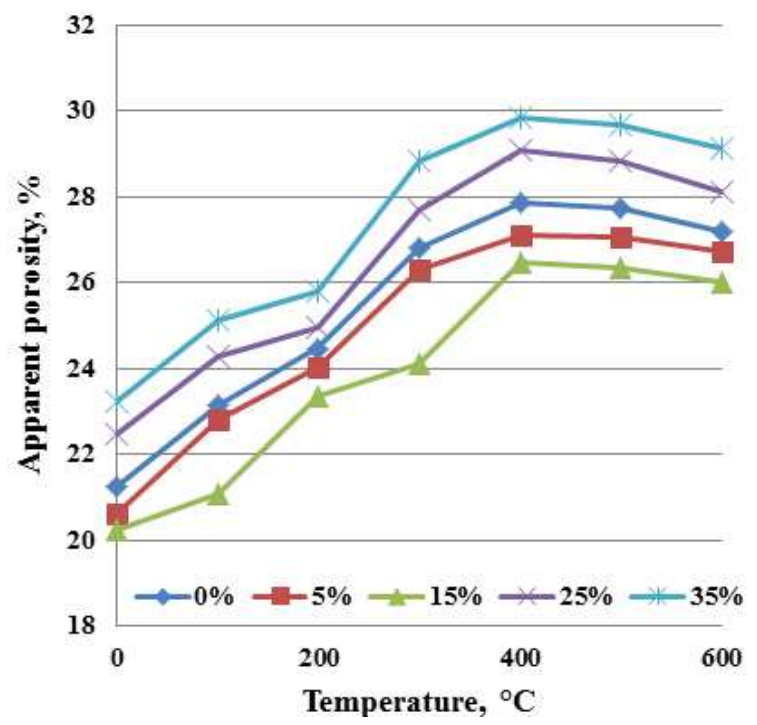

Figure 6. Apparent porosity of cement pastes as a function of temperature up to $600^{\circ} \mathrm{C}$.

The changes in density as well as porosity due to the exposure to temperature from $0-600^{\circ} \mathrm{C}$ were happened in three steps. The density decreased from room temperature until $400^{\circ} \mathrm{C}$ which is due to the removal of free or crystallized water existed in the intermolecular spaces leading to create more open pore volume. As a result, the porosity increased. From $300^{\circ} \mathrm{C}$ till $400^{\circ} \mathrm{C}$, the breaking down of the formed hydrates and/or minerals started. From $400^{\circ} \mathrm{C}$ to $600^{\circ} \mathrm{C}$, it was accompanied by an increase in the density for all cement pastes and a decrease in the porosity. This is mainly attributed to the decomposition of $\mathrm{Ca}(\mathrm{OH})_{2}$. Moreover, the associated shrinkage due to the exposure to high firing temperature was leading to the formation of denser structures as well as higher density and lower porosity. Accordingly, the changes in the porosity are in a good conformity with those of density $[15,16]$.

\subsection{Compressive Strength}

Figure 7 demonstrates the compressive strength of the various hardened cement pastes as a function of temperature. The compressive strength of the OPC cement pastes gradually increased when from $100^{\circ} \mathrm{C}$ up to $500^{\circ} \mathrm{C}$ and then decreased, whereas that of the hardened cement pastes containing $\mathrm{H}$ increased only up to $400^{\circ} \mathrm{C}$ and then decreased. The compressive strength of cement pastes containing 5 and 15 wt.\% Hare higher than that of OPC. This is principally due to the pozzolanic reactions that occurred between Hand the released $\mathrm{Ca}(\mathrm{OH})_{2}$ that was coming during the hydration process to produce additional calcium silicate and/or aluminate hydrates ( $\mathrm{CSH} \& \mathrm{CAH})$ [12, 13, 17]. These hydrates often deposited inside the pore structure of the hardened cement pastes. The decrease of the compressive strength of cement pastes containing 25 and $35-\mathrm{wt} . \% \mathrm{H}$ is mainly contributed to the deficiency of the OPC portion which is the main binding material. This means that the higher addition of $\mathrm{H}$ is undesirable [18, 19]. Moreover, the increase of the compressive strength of cement pastes when 
heated up to 400 or $500^{\circ} \mathrm{C}$ may be due to that fact the thermal treatment strengthened the pastes and increases its hardness. The thermal treatment more than $400-500^{\circ} \mathrm{C}$ came with the opposite result, i.e. the compressive strength decreased. This is certainly contributed to the breakdown of the formed $\mathrm{CSH}$ and/or $\mathrm{CAH}$, particularly with the decomposition of the combined water content which in turn was accompanied with internal cracks [17-19]. The cement pastes containing any pozzolanic materials are more sensitive if exposed to fire. Accordingly, the cement pastes made with $15-25$ wt.\% $\mathrm{H}$ represent the most suitable fire resistant cements up to $600^{\circ} \mathrm{C}$ if compared with other types even that of the OPC pastes taking into consideration that the values of compressive strength of all studied cements are close or near to each others. In a general sense, it could be concluded that although the decrease of density and the increase of porosity up to 400 and $500^{\circ} \mathrm{C}$, the compressive strength increased. On contrast, in spite of increasing the density and the decrease of porosity from 400 to $600^{\circ} \mathrm{C}$, the compressive strength decreased.

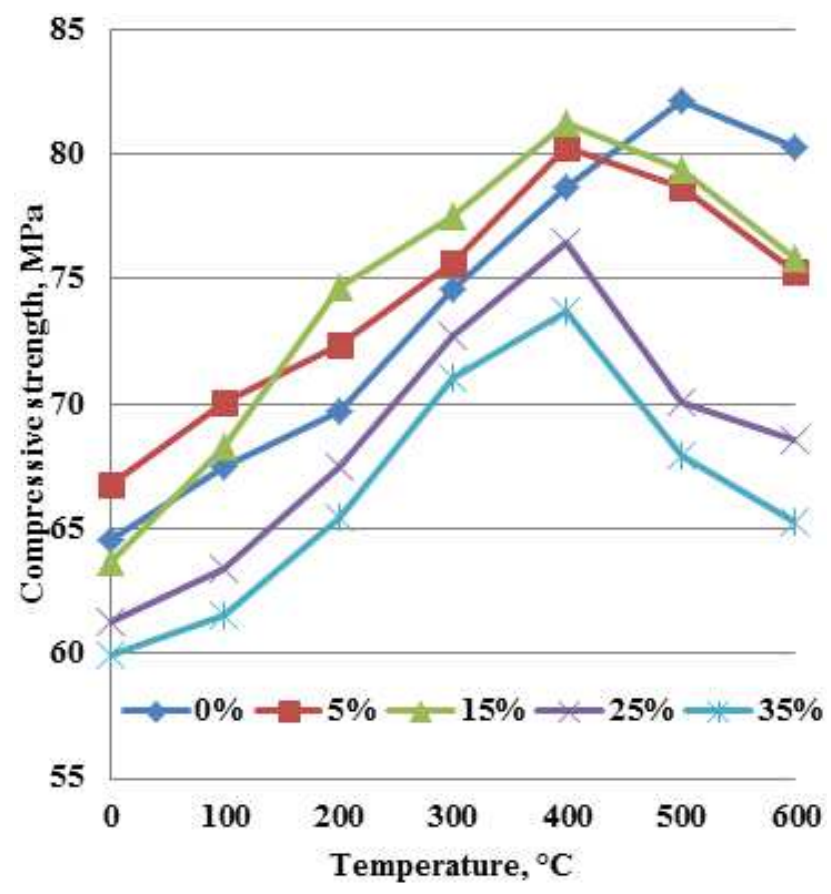

Figure 7. Compressive strength of cement pastes as a function of temperature up to $600^{\circ} \mathrm{C}$.

\subsection{Microstructure}

The SEM images provide us with a useful knowledge on the morphology and crystals of the hydration products. The SEM images of the OPC cement pastes (H0) exposed to 400 and $600^{\circ} \mathrm{C}$ are shown in Figure 8 , whereas those of $\mathrm{H} 4$ exposed to 400 and $600^{\circ} \mathrm{C}$ are seen in Figure 9. Figure 8A shows a microstructure of well-developed crystals of $\mathrm{CSH}$ and/or $\mathrm{CAH}$, while the $\mathrm{Ca}(\mathrm{OH})_{2}$ are spreading in the matrix. At $600^{\circ} \mathrm{C}$ (Figure 8B), there are clearly some or few microcracks. This was leading to a decomposition of the bonds between particles to cause a decrease in density and an increase in the porosity which in turn causes of a sharp decrease in compressive strength.

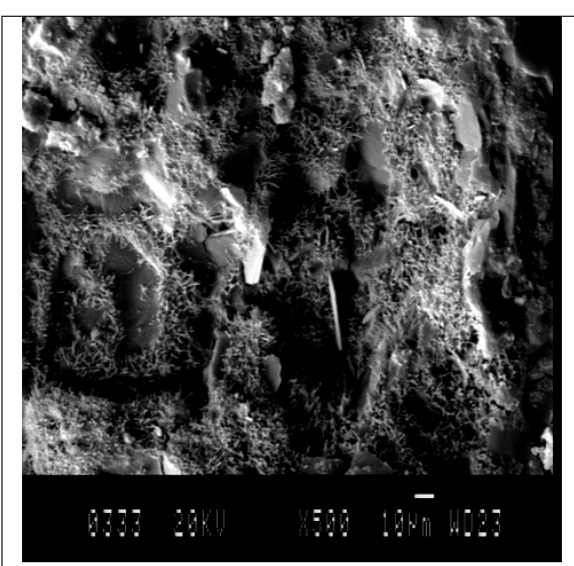

(A) $400{ }^{\circ} \mathrm{C}$

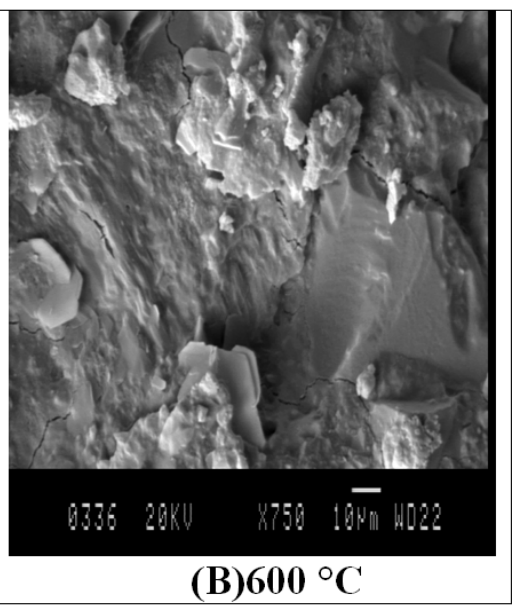

(B) $600{ }^{\circ} \mathrm{C}$

Figure 8. The SEM microscopy of the OPC cement pastes exposed to 400 and $600^{\circ} \mathrm{C}$. 
The $\mathrm{CSH}$ from the pozzolanic reactions between $\mathrm{H}$ and $\mathrm{Ca}(\mathrm{OH})_{2}$ resulted in a consumption of a large quantity of lime (Figure 9). This was reflected positively on the density, porosity and compressive strength, i.e. the density increased and the porosity decreased. This was leading to increase the compressive strength when compared with those of the OPC

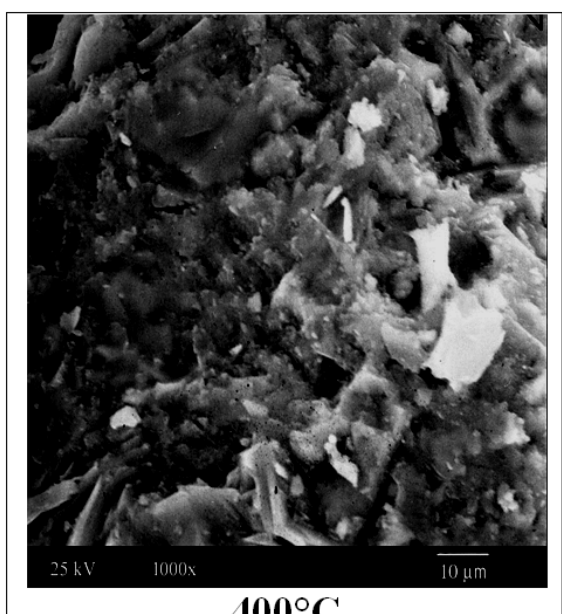

$400^{\circ} \mathrm{C}$ cement pastes. At $400^{\circ} \mathrm{C}$ (Figure 9A), the microstructure indicated the formation of dense masses of hydration products having micro- and narrow pores except that there are some cracks in the matrix which caused the decrease in the compressive strength.

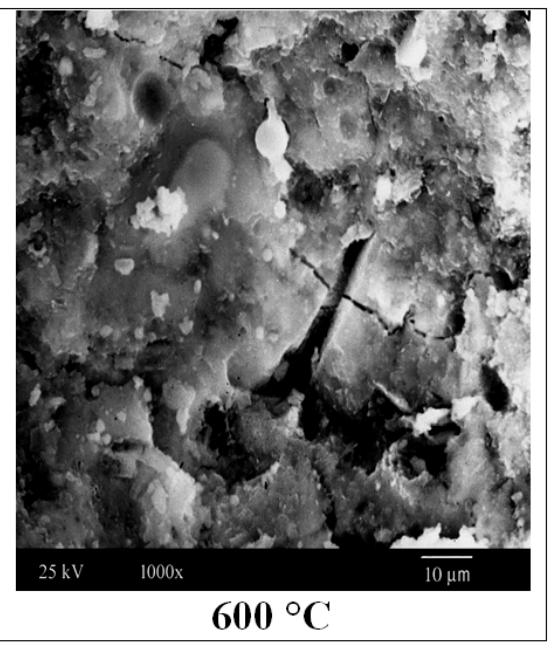

Figure 9. The SEM microscopy of the different cement pastes exposed to 300 and $600^{\circ} \mathrm{C}$ for three hours.

\section{Conclusions}

a. The loss on ignition of the various hardened cement pastes increased with temperature as well as with Homra content.

b. The density decreased with temperature up to 400 or $500^{\circ} \mathrm{C}$ while the apparent porosity increased. More than 400 or $500^{\circ} \mathrm{C}$, the density increased and the porosity decreased.

c. The compressive strength of the OPC pastes gradually increased with temperature up to $500^{\circ} \mathrm{C}$ with those of the OPC pastes and then decreased while those incorporated $\mathrm{H}$ increased only up to $400^{\circ} \mathrm{C}$ and then decreased.

d. The hardened cement pastes with $15 \% \mathrm{H}$ recorded the highest compressive strength value at all firing temperatures.

e. The SEM images showed that a microstructure of welldeveloped crystals of $\mathrm{CSH}$ and/or $\mathrm{CAH}$, while the $\mathrm{Ca}(\mathrm{OH})_{2}$ are spreading in the matrix at temperatures up to $400^{\circ} \mathrm{C}$, while there are some cracks if heated up to $600^{\circ} \mathrm{C}$.

f. It could be concluded that with the addition of $15 \mathrm{wt} . \%$ $\mathrm{H}$ at most, there is no adverse effects. Therefore, the higher content of $\mathrm{H}$ is undesirable. The pastes containing $\mathrm{H}$ are much stable at temperature up to $400^{\circ} \mathrm{C}$ and the decay of $\mathrm{Ca}(\mathrm{OH})_{2}$ started at more than that up to $600^{\circ} \mathrm{C}$.

g. The pure OPC cement pastes could withstand against thermal exposure up to $500^{\circ} \mathrm{C}$ while those incorporated $\mathrm{H}$ could withstand only up to $400^{\circ} \mathrm{C}$.

\section{References}

[1] S. N. Ghosh, S. L. Sarkar \& S. Harsh, "Mineral admixtures in cement and concrete", in: S. S. Rehsi (Ed), Progress in cement and concrete, Vol 4, ABI Books, New Delhi, 1993, 158-173.

[2] F. Pacheco-Torgal, "Biopolymers and Biotech Admixtures for Eco Efficient Construction Materials", WOODHEAD PUBLISHING LIMITED, Sawston, Cambridge, Elsevier Limited. Registered Office: The Boulevard, Langford Lane, Kidlington, Oxford, OX5 1GB, United Kingdom, Registration No. 1982084, Registered in England and Wales, 2015.

[3] H. H. Darweesh, "Effect of the combination of some pozzolanic wastes on the properties of Portland cement pastes" iiCL'industriaitaliana del Cemento, Italy, 808, 2006, 298-311.

[4] H. H. M. Darweesh, "Characteristics of metakaoline blended cement pastes" Sil. Ind. (Cer. Sci. \&Techn.), Belgium, Vol. 72, Nr. (1-2), 2007, 24-32.

[5] H. M. Darweesh and H. M. Awad "Effect of calcination temperature and calcined clay substitution on the properties of Portland Cement Pastes" iiCl'industriaitaliana del Cemento, Italy, 844, 2008, 486-501.

[6] S. S. Rehsiand S. K. Garg, "Heat resistance of Portland fly ash cement", Cement, 4, 2, 1976, 14-16.

[7] S. M. Morsy, A. F. Galaland S. A. Abo-El-Enein, "Effect of temperature on phase composition and microstructure of artificial pozzolana cement pastes containing burnt kaolinite clay”, Cem. Concr. Res., 28, 8, 1998, 1157- 1163.

[8] M. Heikaland H. El-Didamony, "Pozzolanic activity of Homra with lime”, Mansoura Sci. Bull., 26, 1, 1999, 79-95. 
[9] H. El-Didamony, M. Heikaland M. M. Shoaib, "Homrapozzolanic cement", Silic. Ind., 65, Nr. 3-4, 2000, 3943.

[10] M. Heikal, M. Morsyand S. A. Abo-El-Enein, "Electrical conductivity of pozzolanic cement pastes and mortar containing crushed clay bricks (Homra)", The $15^{\text {th }}$ Egypt. Chem. Conf., Nov 20-25, Egy. Chem. Soc., Part II, Cairo, Egypt. 1999, 145-152.

[11] H. H. M. Darweesh Setting, hardening and St. properties of cement pastes with zeolite alone or in combination with slag" Inter Ceram (Intern. Cer. Review), Germany, Vol. 1, 2012, 5257.

[12] ASTM -Standards "Standard Test Method for Normal water of Consistency of Hydraulic Cement", C187-86, 1993, 148150.

[13] ASTM -Standards "Standard Test Method for Setting Time of Hydraulic Cement”, C191-92, 1993, 866-868.
[14] ASTM-Standards "Standard Test Method for Compressive Strength of Dimension Stone", C170-90, 1993, 828-830.

[15] A. M. Neville, "Properties of concrete". $4^{\text {th }}$ edn Essex (UK): Longman, 1995.

[16] P. C. Hewlett, "Lea's Chemistry of Cement and Concrete"; $4^{\text {th }}$ Edn; John Wiley \& Sons Inc., New York, 1998.

[17] H. El-Didamony, H. H. M. Darweeshand R. A. Mostafa, "Characteristics of pozzolanic cement pastes Part I: Physicomechanical properties" Sil. Ind. (Cer Sci \& Techn), Belgium, 73, Nr. 11-12, 2008, 193-200.

[18] J. Piasta, Z. Sawiczand L. Rudzinski, "Changes in structure of hardened cement pastes due to high temperature", Materials Structure, 17, 100, 1984, 291-296.

[19] H. H. M. Darweesh and H. Youssef, "Preparation of $11 \AA$ Alsubstituted Tobermorite from Egyptian Trackyte Rock and Its Effect on the Specific Properties of Portland Cement", Inter Ceram Intern. Cer. Review, 63, 7-8, 2014, 358-362. 